\title{
The Compact vs. the Dispersed City: History of Planning Ideas on Sofia's Urban Form
}

ABSTRACT. This paper reviews the planning history of Sofia since its designation as Bulgarian capital in 1879. It argues that Sofia's planning has been persistently shaped by two perennial dilemmas - how to reconnect the city with nature and how to define its relationship with the region. In response to these dilemmas, different visions, shaped by both local conditions and dominant foreign theories, were proposed at different times. Some promoted a compact city, while others advocated a dispersed form. The case of Sofia demonstrates the significance of the city-nature and the city-region relationships in the evolution of planning thought. It also points to the difficulties which arise when local ideas of how to organize these relationships are inspired by international models made for cities with different historic experiences.

This paper explores stability and change in the evolution of significant urban planning ideas over the 125-year-long history of the City of Sofia as Bulgarian capital. It argues that two fundamental and closely intertwined planning dilemmas-how to reconnect the city with nature and how to define the city's role in the metropolitan region-have provided the framework within which planning debates on Sofia's form have evolved over time. Both dilemmas are, of course, well known from the history of planning in Western contexts. And while the strategies to solve them have shifted over time, the dilemmas have proven to be remarkably persistent, as the case of Sofia illustrates.

Sofia's planning has been significantly influenced by theories which originated abroad: in Western Europe, the Soviet Union and, to a lesser extent, the United States. ${ }^{1}$ This is of course true for many cities around the world, where foreign models of modernization were either imposed by the colonial powers; or in the absence of colonial rule, voluntarily imported by local authorities keen to emulate the "progressive" West. In the case of Sofia as the Bulgarian capital, however, foreign influence has been truly fundamental. As other small Balkan states with a history of long Ottoman rule, Bulgaria has consistently struggled to escape its ostensibly backward past and define itself as a 'modern,' 'European' nation. ${ }^{2}$ To that end, it has eagerly imported Western doctrines, in planning and all else. 
Sofia's case is part of the broader story of the process of diffusion of foreigntypically Western — urban planning ideas across the globe. ${ }^{3}$ According to Ward, ${ }^{4}$ this diffusion tends to fall along a continuum between two extremes. Where the transmittal of planning ideas occurs in a country which is directly controlled by a foreign power (i.e., via a colonial regime), the foreign ideas are imported uncritically with little endogenous input. Where the transmittal takes place between independent countries of relatively equal power, the ideas are analyzed critically and adapted selectively to the local conditions. Bulgaria's case is intermediate because the country has not been-since the end of Ottoman rule in 1878-formally part of an empire, but has consistently depended on foreign powers, both economically and politically. Within this context, it has very eagerly and, to a large extent, voluntarily imported foreign urban planning notions, while adapting them to the domestic conditions.

Perhaps predictably, one significant problem with applying the foreign theories has been that these theories were responses to the specific urban circumstances that prevailed in the countries where the theories originated (most commonly in Western Europe). Sofia's conditions, however, were rather different from those in the West. To resolve the contradiction, Sofia's plans often relied explicitly on foreign-inspired rhetorical postulates, while endowing them with alternative, local meanings. As a result, the popular foreign theories were modified to fit the local conditions and in the process they acquired a vernacular flavor that sometimes ran contrary to the theories' original intent.

The significance of Sofia's story is threefold. First, it contributes to the discussion of two dilemmas that have been central to planning in all parts of the world- the relationship of the city to nature and its position in the larger region. Second, it 
demonstrates the tension which arises when local strategies addressing these dilemmas are based on foreign models made for cities with different historic experiences. The literature on the diffusion of Western planning ideas has already pointed to the difficulties of implementation. ${ }^{5}$ But while attention has been focused on the difficulties arising from the lack of economic or political prerequisites to fulfill the foreign-inspired ideas, ${ }^{6}$ this study highlights the conflicts arising from the fact that local conditions exhibited problems substantially different from those typical of Western cities. Third and perhaps most importantly, the case demonstrates the ambiguous boundary between 'local' and 'foreign' models. Rather than being passive recipients of Western ideas, Sofia's planners often paid 'lip service' to the foreign models, while domesticating their essence as they saw fit. In the process, the foreign models attained a local flavor so distinct that it puts into question whether the models in their final, modified form belonged to either category — local or foreign — and even whether the binary categories exist in the first place.

To present the history of Sofia, the paper relies on primary and secondary sources. These include the series of Sofia's master plans; scholarly, archival and media accounts of Sofia's planning; and related meetings protocols, published interviews, books and articles by the chief actors in the planning processes. To tell the story of post-communist planning, the study also uses several drafts of the latest plan, Sofia 2020, and nearly two dozen interviews with planners involved in its writing, conducted by the author.

The paper is divided into three parts. The theoretical section reviews the evolution of ideas on the relationship between city and nature, and between city and region. It is followed by an account of the debates on Sofia's form during the pre-World-War-II 
period (1879-1939), the communist period (1945-1989) and the post-communist period (1990-2005). The conclusion discusses stability and change in the planning notions of how to shape Sofia, and the interplay between foreign ideas and their local interpretation.

\section{City and Nature, City and Region—an overview of international planning ideas}

Urban planning was established as a profession to amend the deplorable conditions of the $19^{\text {th }}$-century Western city, appropriately labeled "The City of Dreadful Night". Conceived over a relatively short period of time as the unavoidable offspring of the Industrial Revolution, this city offered its inhabitants not only the promise of employment, but also crowding, dirt, smoke, noise and darkness at nightmarish levels that were unknown to the inhabitants of pre-industrial settlements. Predictably, this city came to be seen not only as the stark opposite of the "lost paradise" of pastoral rural life, but also as the grim antipode of nature itself. ${ }^{8}$

The relationship between the industrial city and nature was conflicted from the start. On one side, the city embodied the core promise of the Industrial Revolution and, more broadly, Western modernity, to free humanity from debilitating dependence on nature's whims. ${ }^{9}$ The city, in this view, was the supreme achievement of civilization, while nature was savage and needed to be tamed for human benefit. ${ }^{10}$

Yet, perhaps paradoxically, many observers perceived the severing of the city-nature link as the core root of urban misery. ${ }^{11}$ In their view, cities were a "blasphemy against nature." ${ }^{12}$ Nature, in contrast, was pristine and inspiring. Reconnecting city to nature promised many benefits such as beauty, ampler sunlight and cleaner air, improved sanitation and enhanced public health. Ostensibly, it also provided for moral cleansing of the urban masses. ${ }^{13}$ 
This "dual-scripting" of city and nature — each category being simultaneously good and evil— permeated debates on urban form beginning in the $19^{\text {th }}$ century. ${ }^{14}$ The contradiction was resolved by attempting to engineer a city-nature union which kept only the desirable aspects of each category — a notion perhaps best articulated by Ebenezer Howard in his famous "marriage of town and country."

Almost all significant paradigms of $19^{\text {th }}$ - and $20^{\text {th }}$-century urban planning can be read as replays of the debate on city-nature union. Principally, there are two main approaches through which the union can be achieved: either to allow nature in the city or, conversely, to let the city disperse amid nature. ${ }^{15}$ The latter, as discussed below, inherently mandated a substantial rethinking of the relationship between the city and its region.

The first influential professional planning movement entitled the Monumental City, ${ }^{16}$ which was pioneered by Baron Haussmann in Paris from where it spread globally, ${ }^{17}$ followed the first approach. Planners in this tradition advocated the penetration of the dense urban fabric by islands of carefully landscaped nature in the form of parks, which were commonly conceptualized as the urban "lungs." 18

The replacement of the Monumental City paradigm by avant-garde movements caused a weak relapse in the history of attempts to unite city and nature. Futurists like Tony Garnier, for example, explicitly drew inspiration from technology, not nature. But even they surrounded their machine-age urban utopias with pastoral greenbelts. ${ }^{19}$ Furthermore, when avant-garde evolved into mainstream Modernism, the city-nature relationship moved back to the center stage. Modernists like Corbusier, the chief author of the Athens Charter, as well as Sert, Costa or Niemeyer, all aspired to unite city and nature. ${ }^{20}$ But instead of simply piercing the urban fabric with individual parks, they 
planned to concentrate the population in "towers in the park" and reserve 95 percent of urban land for green space. In so doing, they aimed to convert the whole city into a park and transgress the city-nature polarity that had frustrated earlier planning efforts. ${ }^{21}$ The idea spread around the globe and acquired the status of dominant international paradigm, especially after $1945 .^{22}$

If the Monumental and the Modernist planners aimed to reform the city from the inside, Ebenezer Howard looked beyond the city borders. In Garden Cities of Tomorrow, ${ }^{23}$ he conceived a complete program for urban dispersal, which built on the incipient bourgeois suburban movement. ${ }^{24}$ Howard proposed to solve both the crowding of cities and the desolation of the countryside by engineering a reunion of city and nature (i.e., town and country) in pastoral but self-sufficient Garden Cities, which would house a socially mixed population and would be surrounded by greenbelts. The idea was inherently embedded in rethinking not only of the relationship between city and nature, but also of the relationship between city and region. As settlements were to disperse, the old city and its new neighbors were to form a coherent regional system. And although the city retained its supremacy, the region became clearly polycentric. En par with modernism, Howard's model resonated powerfully across the globe. ${ }^{25}$

This regional—and decentralizing — vision rose to further prominence on both sides of the North Atlantic by the works of such influential thinkers as the American urban historian Lewis Mumford ${ }^{26}$ and the Scottish biologist Patrick Geddes. ${ }^{27}$ Because of its potential to ensure healthier living and a "more equitable distribution of land values," the idea was soon widely perceived as a core goal of planning in the United States and Western Europe ${ }^{28}$ Soviet architects also made their distinctive contribution. Among 
them, the school appropriately labeled as the "De-urbanists" promoted the "greening" of Russia - the abolition of old cities and the dispersal of populations into the countryside. The most famous Soviet scheme was that of Nikolai Milyutin, who proposed the construction of new, linear urban forms surrounded by greenbelts. ${ }^{29}$

American icon Frank Lloyd Wright took the idea to new heights. ${ }^{30}$ Wright, who was famous for his deeply professed love of nature, welcomed the disappearance of all large cities. He proposed a radical dispersal scheme called Broad-acre City, according to which each household should own at least one acre, and all industry should be spread around vast green lands and connected by highways. In his view, this would be the only city that could guarantee individual freedoms and reconnect people with nature.

These early $20^{\text {th }}$-century utopias were taken increasingly seriously through the following decades. Although some of their radical elements were removed, the idea of greening the city center in a Corbusian fashion and dispersing populations in the country was adopted as official policy in many Western countries. The mere fact that mid-century plans were looking at Greater London, Greater Stockholm or Greater Copenhagen points to the shift to regional thinking. ${ }^{31}$ The core idea of such plans was to promote the spread of populations in satellite towns separated by greenbelts. In so doing, the plans aimed to create a polycentric system of settlements all of which, because of the elongated form of the "fingers," would remain close to nature. And while in Europe the greenbelts ensured the relative compactness of new settlements, in America the uncontrolled spread of suburbs produced a system closer to Wright's amorphous Broad-acre City ${ }^{32}$ (for a summary of the international ideas, see Table 1).

\section{INSERT TABLE 1}


Jane Jacobs astutely pointed out what united most "green" (or "De-centrist," as she called them) visions. Whether they were driven by "love" of nature or sought to develop equitable regions, they promoted the dispersal of human activity "throughout large territories, dovetailing into natural resources". ${ }^{33}$ In so doing, however, they promoted the consumption of ever-larger pieces of nature and helped create the problems we today associate with sprawl. ${ }^{34}$

The late $20^{\text {th }}$ century was marked by a global shift in planning zeitgeist. ${ }^{35}$ The main impetus behind the change was the realization of the limits of using natural resourcesrealization which was especially painful for the planning profession since it had historically supported exploiting these resources via urban dispersal. Anthropocentric views of nature were increasingly challenged by views of nature as having an intrinsic value. ${ }^{36}$ Planners became interested in designing in harmony with nature rather than in taming it. ${ }^{37}$ Planning models focused solely on improving human well-being were trumped by a new leading paradigm of sustainable development. ${ }^{38}$ Although sustainability is a multi-faceted concept,${ }^{39}$ which includes economic and social-equity elements, ${ }^{40}$ its emphasis is clearly on the balance between humans and nature. ${ }^{41}$

Related to the sustainability paradigm, a New Regionalism also rose to prominence. The "old" regionalism - the one of Howard, Geddes and Mumford — was a response to specific conditions: crowded but wealthy cities vs. green but poor periphery. But the massive $20^{\text {th }}$-century suburbanization of Western cities caused a role reversal: the city became less crowded but poorer; the periphery more sprawling and richer. It also became increasingly clear that dispersal had unforeseen not only ecological, but also social costs. 
In reaction to the dispersed nature of today's metropolis and the problems of ecological degradation, traffic congestion and inequities between wealthy suburbs and poor cities, the New Regionalism, as well as the other dominant Western planning ideologies which aspire to promote sustainable development (such as Smart Growth and New Urbanism), advocate compact urban forms and the re-urbanization of existing cities. ${ }^{42}$ In this sense, these new models represent a 180-degree reversal of the earlier planning agendas for urban dispersal. ${ }^{43}$ Compact urban forms, as proponents of the new models argue, promise many benefits in efficiency (e.g., compact forms utilize existing infrastructure to its full potential), ecological protection (e.g., compact forms require less car use and thus reduce pollution) and social equity (e.g., compact forms can foster greater social integration). Programmatic policy documents at national and international levels also broadly sustain these views. ${ }^{44}$

Planning in Sofia evolved under the clear influence of all the foreign ideas described above. Yet, local judgment also reflected local conditions, sometimes resulting in interpretations that took the original meaning of the ideas in different directions.

\section{Sofia and its planning, 1879-1939}

Sofia was elected as the Bulgarian capital in March 1879, after the country gained independence from Ottoman occupation. Unlike other European capitals that have been permanent seats of power through medieval history, Sofia was a town of little importance through the 500 years of Ottoman rule. Thus, despite the city's ancient history, most of its fabric was built since the late $19^{\text {th }}$ century, following dominant Western, and later Soviet, planning doctrines. ${ }^{45}$ The first generation of Sofia's planners were all foreign-born architects or engineers; the second, Bulgarian architects educated in Western Europe, 
most notably Germany, Italy and France. All were deeply imbedded in the intellectual wells of mainstream European urbanism. ${ }^{46}$ As a result, early proposals for reshaping Sofia aimed at erasing its Ottoman heritage, and emulated, in modest form, the main Western urban planning ideas of the time - the Parisian boulevards and the Viennese Ring Road. ${ }^{47}$

The debate regarding whether to preserve or disperse the existing city seems to have started in the very year of 1879 . At the time, Sofia was not only small and poor butbecause of its narrow curvy streets and its many buildings inherited from the Ottoman era-also deemed "oriental" ${ }^{48}$ It was hardly a capital city worthy a state intent on joining the European mainstream. Thus came the first de-urbanist idea: to abandon the city and build a brand-new twin on pristine green fields under modern, "European" principles. The idea was ultimately rejected by the Bulgarian Prince A. Battenberg who feared the old town would fall into disarray. ${ }^{49}$

Over the next sixty years, Sofia grew exponentially in population and size. In 1879, its territory was only $3 \mathrm{sq} \mathrm{km} .{ }^{50}$ By 1939 , it had expanded to $42 \mathrm{sq} \mathrm{km}$ by the annexation 53 adjacent villages. ${ }^{51}$ Population rose from 18,000 to 400,000 , making Sofia the fastestgrowing Balkan capital. ${ }^{52}$ The economic profile of the city also changed. From 1904 to 1921 the number of factories quadrupled. ${ }^{53}$ By the early 1930s, industry employed a third of the city population and Sofia was established as the nation's unrivaled industrial center with 50 percent of the Bulgarian industrial workforce ${ }^{54}$ Natural growth and the influx of rural migrants seeking industrial jobs in the city - trends typical for all large European cities at the time - partially caused this phenomenon. In Sofia's case, fast growth was further facilitated by the entry of many thousands refugees expelled from territories lost 
in the Balkan wars. These dramatic changes made Sofia stand in the eyes of its contemporaries as a city whose fast growth was comparable to that of North American and Bavarian industrial cities in the mid-to-late $19^{\text {th }}$ century. ${ }^{55}$

With fast growth and industrialization came predictable problems reminiscent of those that had overwhelmed Western cities since the $18^{\text {th }}$ century. Central Sofia became more crowded and polluted. ${ }^{56}$ And although there were many plans to reshape its streets,${ }^{57}$ none addressed the urban problems comprehensively. Under these conditions, foreign ideas for uniting the city with nature attracted increasingly favorable attention among the local planners. The views of E. Howard and F. L. Wright, in particular, gained notoriety through the work of T. Trendafilov and G. Nenov, who published variations of Garden Cities in 1912 and $1924 .{ }^{58}$ A few years later, Sofia's Chief Architect T. Goranov ${ }^{59}$ praised dispersal as the correct "system adopted by all English and German cities."

The first master plan for Building Greater Sofia was prepared from 1934 to 1938 (see Figure 1). The plan was put together under the leadership of the German Nazi-backed architect A. Muesmann, whose victory in an international competition occurred under dubious conditions, most likely having to do with Bulgaria's alliance with Germany. ${ }^{60}$ The plan was prepared at the height of Garden Cities popularity and it incorporated its chief elements. ${ }^{61}$ It aimed to convert Sofia into a conglomerate of Garden Cities. ${ }^{62}$ According to Chief Architect Goranov, ${ }^{63}$ Greater Sofia was to acquire a "star-shaped form," in which the urban areas, extending like fingers from the center, would be separated from each other by greenbelts (or urban "lungs.") The "lungs" held many virtues: beauty, health, and even protection from foreign gas attacks. The city center was 
to be alleviated from congestion by dispersing some civic functions among the new garden districts. Greater Sofia was thus to attain a polycentric form (Figure 1; for a summary of Sofia's plans and their relationship to foreign ideas, see Table 2). ${ }^{64}$

\section{INSERT FIGURE 1 AND TABLE 2}

The new Sofia would offer its citizens twice more than the existing green space. The dramatic increase in greenery was to be achieved first by creating several large new public parks, but also by raising the amount of open space required per lot and limiting multi-family housing. Unlike some leftist followers of Howard's theory, Muesmann strongly believed that private land- and homeownership served to connect people to 'nature' and 'our roots,' and build healthy national values. ${ }^{65}$ Thus, he proposed that the new building block of Sofia be the quaint single-family house with a large yard—an idea which presented a stark contrast to the apartment blocks in the existing central districts of Sofia, where the bourgeoisie lived.

There were several ways in which the plan's "green" vision did not fit local realities. First, unlike British and German cities, Sofia showed few, if any, signs of upscale suburbanization-its upper classes were steadily entrenched in the center. ${ }^{66}$ Judging from the City Council's debates on the plan, ${ }^{67}$ Sofia's elites were happy to accept the Garden City theory in principle, particularly when it came to building parks, but were uncertain of why people of means would be expected to give up living in the city altogether.

This was linked to another problem. As in other growing cities in poor nations, from Istanbul ${ }^{68}$ to Rio, ${ }^{69}$ Sofia's outskirts were growing as shanty towns inhabited by poor rural migrants. Sofia's periphery also housed the even poorer war refugees. The very idea of dispersal thus ran contrary to what Sofia's elites, including the local planners, 
perceived as a pressing problem. At issue was the fact that the residents of Sofia's

outskirts were so destitute that they had made their huts where land was cheapest—as far from any built infrastructure as possible. ${ }^{70}$ The city was widely perceived as already too dispersed and its authorities doubted resources could ever be found to service the already built far-out areas or fund any further dispersal. Thus, the plan's task, which was defined well before Muesmann arrived, was paradoxical: to disperse the city by moving out some business and civic functions, and yet to shrink the total urbanized areas. ${ }^{71}$

This paradox was resolved in that the plan proposed to concentrate growth in selected built-up areas, while clearing all development from other outlying districts and making them into greenbelts. The idea of urban clearance attracted heated controversy, including the disdain of leftist intellectuals. Desperate citizens almost attacked City Hall protesting that their neighborhoods would be "converted into mighty forests, as if Sofia's future is in raising wildlife." ${ }^{, 72}$ At the end, the plan had few allies on either left or right and concrete steps to implement it were not taken. ${ }^{73}$

\section{Planning communist Sofia, 1945-1989}

After the communist victory in 1945, Muesmann's plan was discarded as bourgeoisfascist. A new plan, under the lead of L. Tonev, was adopted in $1945 .{ }^{74}$ Tonev was Muesmann's sharpest critic. In 1939, he wrote a piece on the "biggest mistakes of Muesmann's plan," where he claimed that: the urban dispersal idea was not fit for Sofia, since it was already too spread-out; building satellite towns was not fiscally sound, since Sofia has less resources than Western cities; and clearing housing occupied by the poor was anti-social. After 1945, he added another charge: that single-family housing was contrary to socialist ideals, since "It is the yard that makes the bourgeois.",75 
The major task of Tonev's plan was rebuilding. Sofia had experienced substantial war damage $\left(12,000\right.$ buildings were leveled by bombs $\left.{ }^{76}\right)$, yet there was no Marshall Plan on the horizon nor immediate Soviet aid. Because of the limited funds, the focus was on infill and improving the efficiency of the existing infrastructure. Sofia was to stay within its borders of $40 \mathrm{sq} \mathrm{km}$. Dispersal of any type was no longer on the agenda.

But behind this shift, some of Muesmann's main ideas - these for a green and polycentric Sofia—were carried on.$^{77}$ Like his predecessor, Tonev sought the relocation of downtown functions to neighborhood nodes. He also advocated creating radial greenbelts extending from the center toward the outskirts and separating the urban districts, but without clearing any poor built-out areas. The main difference was in organizing the greenery. In line with the prescriptions of the Athens Charter, the new building block of Sofia was no longer to be the single-family home, but the group of apartment buildings around a shared green space. ${ }^{78}$

If Muesmann overestimated the need for Sofia's spatial growth, Tonev underestimated it. After the mid-1950s, migration toward Sofia intensified as a result of the building of large industrial facilities, which attracted thousands of provincial workers. Tonev's plan foresaw a population of up to 800,000 in 1975 , but by 1955 population had reached 600,000. In 1956, the Council of Ministers required a new plan. Two teams were selected to develop alternative plans, one led by L. Neikov and one by V. Siromahov.

Neikov's team kept close to Tonev's idea for a modernized but compact city. It sought to keep Sofia in its borders and further utilize infill opportunities. Neikov explained his views in a textbook published a few years before the plan. He claimed that "modern [socialist] planning rejects the unbridled expansion of cities." Under capitalism, 
he argued, the formation of bourgeois suburbs was an unfortunate process that exacerbated the tensions between center and periphery. But socialist planning aimed to provide good living conditions to all urban dwellers, and thus could not endorse the chaotic growth of settlements with anti-urban character. ${ }^{79}$

Siromahov offered an alternative philosophy, also ostensibly grounded in Marxist thought. Indeed, the main problem of capitalist Sofia might have been the disparity between the bourgeois center and the poor periphery. And indeed the growth of suburbs or garden towns may be yet another failed capitalist recipe. But if the socialist state were to build a new type of urban periphery, which offers the working class excelling living conditions in modern socialist blocks, the conflict between center and periphery would be resolved in full harmony with socialist values. Siromahov thus proposed a significant expansion of the urban borders. Large new estates were to be built upon former farmland by using Modernist design principles (see Figures 2 and 3). ${ }^{80}$

\section{INSERT FIGURE 2 AND FIGURE 3}

In 1961, Neikov's vision was chosen as Sofia's new master plan. ${ }^{81}$ Justification of the Council of Ministers' final decision came in the typically vague language used by communist bureaucracy. According to Tonev, ${ }^{82}$ who was one of the key consultants to the Council, the plan provided for the "correct socialist reconstruction of the city by building up the existing urban territories." But the decision was most likely grounded in economics - a new urban periphery would require too many resources; Neikov's vision of a compact city was thus deemed more realistic. 
In the meantime, building methods using factory-made panels were imported from the USSR. This changed the economic equation, as the new technology allowed for massive economies of scale. Building a new periphery was no longer beyond Sofia's means.

In 1963, a plan update was adopted which embraced the once-rejected Siromahov's vision. Following the Soviet lead in mass-produced housing, the update proposed several large estates comprising thousands of housing units around new civic nodes. Sofia was to finally become polycentric. For the next 25 years, quarter million new units were built upon thousands of hectares of farms. Today they house two-thirds of Sofia's population.

In line with the Athens Charter and the communist commitment to collective spaces $^{83}$, the new districts provided massive amounts of public greenery between buildings. This by itself required urban expansion. But the building method also mandated the conquest of new lands. The economies of scale could only be achieved if the giant cranes lifting the panels could function on vast clean areas. ${ }^{84}$ As one of the designers of the new estates noted: 'We could not have stayed within the borders of the existing city — the cranes and the lines of panels required expansion. ${ }^{, 85}$

From 1961 to 1989 Sofia went through a series of plan updates, but a new master plan was never adopted. Thus, the end of socialism found the city with a much outdated plan.

\section{Post-communist plans, 1989-2005}

The year 1989 brought radical changes to Bulgaria and its capital city. The early- and mid-1990s were a period of severe economic crisis, dwindling incomes, growing class segregation and a sharp political turn to the right. The Bulgarian economy crashed, inflation ranged from 40 to 80 percent annually, and GDP fell by a third. ${ }^{86}$ And although 
conditions in the capital were always better than those in the rest of the country, in 1997 Sofia's poverty rate reached 37 percent. $^{87}$

Economic recovery started in 1998 (current Bulgarian GDP growth rates are 5 percent). By then, most of the state assets and enterprises, including the massive homebuilding companies that erected the socialist housing estates, were broken apart and privatized (by 2000, the private-sector share of GDP reached 70 percent starting from 9 percent in $1990^{88}$ ). The state largely withdrew from housing production. As of 2000 , over 90 percent of all new dwellings were privately built. ${ }^{89}$ Simultaneously, land that had been nationalized by the communist regime in $1947-8$ became eligible for sale and/or return to its pre-war owners.

Under those conditions, two areas of Sofia have changed most visibly. The first includes downtown and a few upscale neighborhoods near it (e.g., Lozenetz and Iztok), which have experienced substantial infill in the form of upper-middle-class housing or small- to medium-scale commercial development. The second are the urban fringe areas, particularly those along the southern periphery, in the outskirts of the mountain Vitosha. The Vitosha district in fact experienced a 50-percent increase in the number of dwelling units in less than a decade. ${ }^{90}$ In Vitosha and other similar outlying areas, the dominant unit is the upscale single-family house with a yard. Since the late 1990s, the outskirts have also attracted a substantial number of large commercial operations, including hypermarkets, warehouses, entertainment complexes and office parks. ${ }^{91}$ For the first time in Sofia's history, then, one may truly speak of notable upper-class residential suburbanization and commercial decentralization. 
The first attempts to provide a new plan for Sofia began immediately after the end of communism. In 1990, the municipality organized a national planning competition, in which 26 teams took part. Of those, 14 teams sought urban dispersal, 8 by building autonomous satellite towns separated by greenbelts, and the rest by expanding Sofia's borders and directing new low-density residential growth toward the green areas in the mountain outskirts. Despite the fact that no population growth was projected, some entries went as far as to advocate expanding the urbanized areas by 40 percent to allow for low-density living "amid nature," or even to erect an entire large new "mirror center" to counterbalance the existing downtown. Almost unanimously, the proposals sought to decentralize downtown functions to peripheral districts or autonomous satellite towns, and thus create a polycentric metropolis. ${ }^{92}$

Because of the unstable economic and political conditions in the early 1990s, however, the preparation of the master plan was terminated. The process was re-initiated in 1998, after the stabilization of the economy, when the Parliament finally adopted a law on the preparation and approval of a new master plan. ${ }^{93}$

The new master plan, Sofia 2020, took five years to prepare, from 1998 to 2003. In 2003, a coalition of non-governmental organizations argued that implementing the plan would cause harm to the mountain areas surrounding Sofia and mounted a legal challenge to the Environmental Impact Assessment that followed the plan. The courts ruled against the environmental coalition, and the Municipal Council adopted the master plan. Yet, as of 2006, the plan still awaits the approval of the National Parliament.

The planning process went through many stages and was organized as an urban design contest. ${ }^{94}$ Once the basic data was compiled, a nationwide competition was held in 
1998. Thirty-four teams took part. As in the early 1990s, around half of the teams proposed developing Sofia in new territories on green fields. ${ }^{95} \mathrm{~A}$ jury awarded several entries. Then an expert team synthesized the ideas from the winning entries, and split in two to produce two competing scenarios: "A" and "B". ${ }^{96}$ According to municipal documents, the scenarios differed in which economic forecast they used: "A" assumed less economic growth and promoted infill; "B" counted on higher growth and favored spatial expansion. ${ }^{97}$ In this sense, the process recalled 1961, when the plan was the outcome of a competition between Neikov's vision of a compact city and Siromahov's vision of a dispersed city (see Figures 4 and 5).

\section{INSERT FIGURE 4 AND FIGURE 5}

The two alternatives shared the goal of transferring functions from the central city to the periphery (i.e., by relocating certain major administrative buildings) and thus creating a polycentric metropolis. They disagreed, however, on the extent to which this should occur. The team behind Scenario "A," led by Motev and Alexandrov, argued that while both the center and periphery might benefit from some functional reorganization, no further residential dispersal is necessary. The existing areas, in their view, included vacant territory sufficient to allow the building of 260,000 new dwelling units-far more than necessary in the conditions of minimal population growth. Thus, they recommended a set of policies to encourage medium-density residential reconstruction and infill.

In contrast, the team behind Scenario "B," led by Stajnov and Mihajlovich, promoted the benefits of "dispersed living amid nature, since it is an expression of new forms of spatial organization that correspond to information society." Suburban housing, they argued, is appropriate for the growing upper-middle class. It would enable Sofia to catch 
up with trends in the cities of the developed democracies. ${ }^{98}$ These excerpts from

interviews with the team leaders illustrate the contrast in visions:

Team leader, Scenario A: "The thesis that our group advocated was that Sofia needs to stop expanding. It has grown enough and from now on it must only become better organized. Under socialism, the city already incorporated too many vast new territories, which currently it can barely manage... From now, the focus must be on improving the assets we already have. This is the right, the sustainable thing to do-both economically and environmentally. And it is, I believe, the philosophy of Western cities at the moment."

Team leader, Scenario B: "Currently, $93 \%$ of the population of metro-Sofia lives in the City. Only $7 \%$ lives outside of it. Now we all know that all over the world, particularly in the developed democracies, cities have much more developed and often elite peripheries. People who can afford to leave the compact city in order to live in a more natural environment have already done it. So our long-term goal is to create the prerequisites that will enable part of the city population to move out so that Sofia can catch up with the global trends....Thus, our alternative is the dispersed city. We want the region around Sofia to be inseparable from it and adopt functions that would relieve the pressures now piling upon the compact city. There will be secondary centers of activity in what is now the periphery. Then the region around the city will be equal to the city itself.

Dispersed urbanization is the regional and more equitable approach. And this type of new regional thinking is well known in the West... We want to encourage new types of dwellings, in a new type of environment of a totally different character, and encourage a lifestyle that is closer to nature. People are totally fed up with this over-urbanized environment that is now offered in the compact city - an environment that contradicts the basic tenets of sustainable development... Our people crave to live amid nature. In socialist times, the government had interest in cramping people in high-density housing estates because this would save it money. But in a market economy, in an information-type society, in a democracy, the compact city is no longer the right choice."

The debate between proponents of the two scenarios was resolved in 2002 when the

latter — the urban dispersed model — was adopted as the basis of the plan's final draft. ${ }^{99}$

Following the ideas of Scenario "B," this draft recommended:

"Dispersed living amid nature, an expression of new forms of spatial organization inherent to the information society and enabled by advanced communication technology, should be encouraged."

"It is not necessary to utilize the whole potential of the existing territory. The growth of residential areas should be related to the growth in the standard of living rather than population growth. The already overpopulated existing urban areas should only be renovated, keeping in mind that the correlation between high urban density and poverty is so obvious that it needs no further proof."

Behind the difference in visions - one for a compact city which was dismissed, and

one for a dispersed city which was endorsed-lurks a theme that seems to penetrate

Sofia's history. Both visions aimed to position themselves within the framework of

popular current international ideological tenets, in this case regionalism and

sustainability. These ideologies were, however, endorsed with contested meanings. The 
authors of "A" linked them to compact form, while the authors of "B" linked them to dispersed forms. But how can such contested interpretations co-exist? How can the authors of "B" claim that sustainability means dispersal, in conflict with common international interpretation? The first logical explanation - that they are unaware of dominant international ideas — can be easily refuted. Based on the interviews, it is clear that they are highly educated individuals with a firm grasp of current planning theory. A more plausible explanation was offered by one of the advocates of dispersal:

"Obviously, we are familiar with this new trend in the West- to try to limit growth of the urban areas and encourage people to come back to the compact city. But we are simply not there! ... We are all for sustainable development and regionalism. But what those things mean there, they may not mean here."

Tapping into popular rhetoric for sustainability and regionalism, the authors of the dispersed city model thus endowed the concepts with a meaning different from the one common in the international planning literature: equitable regionalism for them meant transferring people from the center to the periphery; sustainability meant dispersal "amid nature." This, however, is exactly the interpretation of regionalism and sustainability that prevailed in Western thought earlier in the $20^{\text {th }}$ century. That this interpretation is strong in Sofia is not surprising, if we take into account that today's Sofia displays conditions similar to those of Western cities in the early $20^{\text {th }}$ century. Despite the incipient residential and commercial decentralization, Sofia is substantially more compact than most Western cities. ${ }^{100}$ Downtown is densely populated ${ }^{101}$ and is a thriving business node. ${ }^{102}$ Housing demand in the center is strong, as evidenced by the fact that housing prices there exceed those even in the most fashionable new suburbs. ${ }^{103}$ Thus, Sofia today is far from having a weak center and a sprawling rich periphery—-the context within which Western notions for the benefits of compact forms developed. In a sense, today's situation recalls the 1930s, when local conditions also exhibited problems diverging from 
those typical of Western cities. In the 1930s, the foreign theory of dispersal could not be easily reconciled with the fact that Sofia already had a periphery which, from the viewpoint of its elites, was too spread-out and too poor. In the 1990s, the foreign theory of urban revitalization could not be easily applied to a city which had not lost much of its vitality to suburbanization. In both cases, local plans paid "lip service" to foreign ideas and used them as sources of legitimacy, but re-interpreted their core meaning.

Because of the divorce between influential foreign ideas and the local context, current debates in Sofia offer us a rare glimpse into a condensed history of Western planning thought. We observe the simultaneous juxtaposition of contested interpretations of fundamental planning concepts for the correct relationship between city and nature, and city and region. In Western thought, there has been a clear evolution as one notion has over time taken precedence over the other. In the early $20^{\text {th }}$ century, the prevalent idea was that urban forms should disperse amid nature and the central city should distribute resources to the surrounding settlements. In the early $21^{\text {st }}$ century, the dominant idea seems to be the opposite - that human settlements should be compact and the central city strengthened. In a city like Sofia, however, which is heavily influenced by Western ideas in all aspects of life but has local conditions closer to those of Western cities in the past, the polar visions exist contemporaneously, side by side. Both visions seek legitimacy using Western rhetoric. But while one builds on current Western ideas that favor compact form, the other carries on historic Western notions of the virtues of dispersal. The fact that it was the dispersal vision that was formally endorsed shows that foreign ideas, no matter how well known or progressive they may be, cannot be easily forced upon a local context that does not exhibit the conditions that led to the maturation of these ideas. 


\section{Conclusion}

This paper reviewed the evolution of planning ideas on Sofia's form and, more particularly, the influence of foreign theories and their interplay with local conditions. The evidence suggests that Sofia's planners broadly followed the main international paradigms and, much like their colleagues abroad, struggled to define the relationship between the city and nature, and the city and its region. These two fundamental notionsof city and nature, and city and region — in fact provided the framework within which debates on Sofia's form occurred. There was a remarkable consistency in attempts to promote the emergence of a polycentric city—efforts which were typically frustrated by the government's inability to invest sufficiently in the urban periphery. There was also a consistency in efforts to integrate city and nature, although strategies of how to achieve this varied. All plans advocated more parks. But while those prepared under right-wing governments (in the 1930s and 1990s) championed single-family living with large yards, those prepared under left-wing regimes (1945-1989) promoted shared green spaces.

Sofia's strived to modernize itself using ideas, which originated in the "developed" countries. But these ideas were not absolutes, but malleable concepts which could be given multiple, even conflicting meanings depending on the local economic and political context. Sofia in the 1930s and 1990s provides obvious examples: the first when the Garden Cities idea came to mean both urban dispersal and shrinkage, and the second when current notions of regionalism and sustainability were equated with suburbia. The mid-century plans, albeit to a lesser degree, also did their share of molding classic foreign planning models with a Marxist twist as to justify either socialist rebuilding or expansion. 
Of course, following foreign dogmas when they do not fit the local conditions may be a recipe for disaster. In this sense, Sofia's planners should be lauded for not following international ideas slavishly but for adapting them creatively. Yet, in my view, the latest plan of Sofia holds few promises for urban betterment. As Nedovic-Budic ${ }^{104}$ argues, East European cities have many qualities which their Western counterparts have lost but would like to re-achieve in the future. They have vibrant centers, and are relatively compact and less class-segregated. Clearly, under these conditions, Western ideas to strengthen the city center and restrict sprawl have a limited appeal. However, as residential and commercial decentralization are on the rise globally, it is important to realize that compactness and a thriving center are advantages that can be lost. Postcommunist planners have the unique opportunity of observing the results of planning policies that encourage urban decentralization — consequences that are painfully visible in many sprawling Western metropolises, especially in the United States. While there may be some benefits in encouraging the transfer of some functions from the city center to the periphery, post-communist planning should not repeat Western mistakes of the past. 


\begin{tabular}{|c|c|c|c|c|c|c|c|c|c|}
\hline Timeline & $\begin{array}{l}\text { Dominant and affiliated } \\
\text { international paradigms }\end{array}$ & $\begin{array}{l}\text { Chief } \\
\underline{\text { concerns }}\end{array}$ & $\begin{array}{l}\frac{\text { Influential }}{\text { planners/ }} \\
\text { theorists }\end{array}$ & $\begin{array}{l}\text { Influential } \\
\text { city plans/theories }\end{array}$ & $\begin{array}{l}\text { Concern over } \\
\underline{\text { city-nature }} \\
\underline{\text { integration }}\end{array}$ & $\begin{array}{l}\frac{\text { Method of }}{\text { city-nature }} \\
\text { integration } \\
\end{array}$ & Urban form & Density & $\frac{\text { Regionalist }}{\text { perspective }}$ \\
\hline $\begin{array}{l}1860- \\
1940\end{array}$ & \begin{tabular}{ll}
\multicolumn{2}{l}{ Monumental City } \\
$\circ$ & Beaux Arts \\
$\circ$ & City Beautiful \\
$\circ$ & Stadebau \\
$\circ$ & Socialist "realism"
\end{tabular} & $\begin{array}{l}\text { Aesthetical/ } \\
\text { some social }\end{array}$ & $\begin{array}{l}\text { Haussmann } \\
\text { Olmstead } \\
\text { Burnham } \\
\text { Todd } \\
\text { Bennett } \\
\text { Griffin } \\
\text { Lutyens } \\
\text { Forestier } \\
\text { Rotival } \\
\text { Brunner } \\
\text { Mordvinov } \\
\text { Speer }\end{array}$ & $\begin{array}{l}\text { Paris 1860s } \\
\text { Washington } 1902 \\
\text { Cleveland } 1903 \\
\text { Ottawa } 1903 \\
\text { Chicago } 1909 \\
\text { Canberra } 1912 \\
\text { Delhi 1913 } \\
\text { Havana 1926 } \\
\text { Caracas 1930s } \\
\text { Santiago 1933 } \\
\text { Moscow 1937 } \\
\text { Berlin 1937 }\end{array}$ & YES & $\begin{array}{l}\text { Penetration of the } \\
\text { dense urban fabric } \\
\text { with vast public } \\
\text { parks (urban lungs) }\end{array}$ & $\begin{array}{l}\text { Relatively } \\
\text { compact }\end{array}$ & Moderate & $\begin{array}{l}\text { Focus on } \\
\text { existing cities; } \\
\text { some regionalist } \\
\text { perspectives } \\
\text { (Chicago 1909). }\end{array}$ \\
\hline $\begin{array}{l}1900- \\
1960\end{array}$ & $\begin{array}{cl}\text { Garden } & \text { Cities } \\
\circ & \text { De-urbanism } \\
\circ & \text { 'Disappearing' city } \\
\circ & \text { Metrpolitanism } \\
\circ & \text { Regionalism } \\
\circ & \text { New towns }\end{array}$ & $\begin{array}{l}\text { Social/some } \\
\text { functional \& } \\
\text { economic }\end{array}$ & $\begin{array}{l}\text { Howard } \\
\text { Unwin } \\
\text { Stein } \\
\text { Mumford } \\
\text { Milyutin } \\
\text { FL Wright } \\
\text { Semionov } \\
\text { Abercombie }\end{array}$ & $\begin{array}{l}\text { Letchworth } 1904 \\
\text { Hampstead } 1905 \\
\text { Radburn } 1926 \\
\text { New York } 1929 \\
\text { Stalingrad } 1931 \\
\text { Broad Acre } 1932 \\
\text { Moscow } 1935 \\
\text { London } 1944\end{array}$ & YES & $\begin{array}{l}\text { Dispersing urban } \\
\text { populations across } \\
\text { the countryside/ } \\
\text { constructing new } \\
\text { towns separated by } \\
\text { greenbelts; Mix of } \\
\text { public and private } \\
\text { green spaces }\end{array}$ & \begin{tabular}{|l|} 
Moderately \\
to extremely \\
dispersed
\end{tabular} & \begin{tabular}{|l|} 
Low to \\
moderate
\end{tabular} & $\begin{array}{l}\text { Strong focus on } \\
\text { regionalism: } \\
\text { transferring } \\
\text { populations and } \\
\text { functions from } \\
\text { central city to the } \\
\text { periphery/region. }\end{array}$ \\
\hline $\begin{array}{l}1920- \\
1980\end{array}$ & $\begin{aligned} & \text { City Efficient } \\
& \circ \text { Futurist city } \\
& \circ \text { Functional city } \\
& \circ \text { Modernist city } \\
& \circ \text { Urban renewal }\end{aligned}$ & $\begin{array}{l}\text { Functional/ } \\
\text { technical/ } \\
\text { some social } \\
\text { \& economic }\end{array}$ & $\begin{array}{l}\text { Garnier } \\
\text { Corbusier } \\
\text { Moses } \\
\text { Niemeyer } \\
\text { Costa } \\
\text { Doxiadis } \\
\text { Tange } \\
\text { Khan }\end{array}$ & $\begin{array}{l}\text { Industrial city } 1917 \\
\text { Radiant city } 1935 \\
\text { New York 1930s-50s } \\
\text { UN complex 1947 } \\
\text { Brazilia 1957 } \\
\text { Islamabad 1960 } \\
\text { Tokyo 1960 } \\
\text { Dhaka } 1961\end{array}$ & YES & $\begin{array}{l}\text { Concentrating } \\
\text { urban populations } \\
\text { in tall towers/ } \\
\text { transforming the } \\
\text { city into a park; } \\
\text { Massive public } \\
\text { green spaces }\end{array}$ & $\begin{array}{l}\text { Relatively } \\
\text { compact }\end{array}$ & \begin{tabular}{|l|} 
High to \\
very high
\end{tabular} & $\begin{array}{l}\text { Focus on } \\
\text { existing cities; } \\
\text { some regionalist } \\
\text { perspectives } \\
\text { when combined } \\
\text { w/ Garden Cities }\end{array}$ \\
\hline $\begin{array}{l}1970- \\
2005\end{array}$ & $\begin{array}{cl}\text { City } & \text { Sustainable } \\
\circ & \text { Smart growth } \\
\circ & \text { New urbanism } \\
\circ & \text { New regionalism }\end{array}$ & $\begin{array}{l}\text { Ecological; } \\
\text { some social/ } \\
\text { aesthetic \& } \\
\text { economic }\end{array}$ & $\begin{array}{l}\text { Jacobs } \\
\text { McHarg } \\
\text { Gehl } \\
\text { Duany }\end{array}$ & $\begin{array}{l}\text { Livable city } 1961 \\
\text { Design w/ nature } 1969 \\
\text { Pedestrian city } 1971 \\
\text { Seaside } 1978\end{array}$ & YES & $\begin{array}{l}\text { Preserving green } \\
\text { spaces outside the } \\
\text { urban borders; } \\
\text { providing human- }\end{array}$ & $\begin{array}{l}\text { Relatively } \\
\text { compact }\end{array}$ & Moderate & $\begin{array}{l}\text { Focus on re- } \\
\text { urbanization and } \\
\text { rebuilding of } \\
\text { existing cities; }\end{array}$ \\
\hline
\end{tabular}




\begin{tabular}{|c|c|c|c|c|c|c|c|c|}
\hline $\begin{array}{l}\frac{\text { Time of }}{\text { writing/ }} \\
\text { Main } \\
\text { author(s) }\end{array}$ & $\begin{array}{l}\text { Dominant international } \\
\text { paradigm endorsed in } \\
\text { the local master plan }\end{array}$ & $\begin{array}{l}\text { Local constraints, } \\
\text { goals and ideas }\end{array}$ & $\begin{array}{l}\text { Concern } \\
\text { over city- } \\
\text { nature } \\
\underline{\text { integration }}\end{array}$ & $\begin{array}{l}\text { Concern over } \\
\text { strengthening } \\
\underline{\text { the region }}\end{array}$ & $\begin{array}{l}\text { Method of regional re- } \\
\text { organization and } \\
\text { city-nature integration } \\
\text { proposed in the plan }\end{array}$ & $\begin{array}{l}\frac{\text { Urban form }}{\text { proposed in }} \\
\text { the plan }\end{array}$ & $\begin{array}{l}\text { Density } \\
\text { endorsed } \\
\text { in plan }\end{array}$ & $\begin{array}{l}\text { Local interpretation of } \\
\text { foreign ideas as exhibited in } \\
\text { local planning strategies; } \\
\text { Implementation of plan }\end{array}$ \\
\hline $\begin{array}{l}\text { 1934-1938 } \\
\text { Muesmann }\end{array}$ & $\begin{array}{l}\text { Garden Cities } \\
\text { Monumental City } \\
\text { (only partially) }\end{array}$ & $\begin{array}{l}\text { City is polluted and } \\
\text { lacks parks; Center } \\
\text { is overburdened; } \\
\text { Yet housing for the } \\
\text { poor is in far-out } \\
\text { areas and city is } \\
\text { already too } \\
\text { dispersed; There } \\
\text { are no funds to } \\
\text { sponsor further } \\
\text { urban dispersal. }\end{array}$ & YES & Strong & $\begin{array}{l}\text { Moving certain functions } \\
\text { to periphery; Dispersing } \\
\text { middle classes in garden } \\
\text { towns; Clearance of poor } \\
\text { far-out areas to cut further } \\
\text { need for infrastructure; } \\
\text { Dominance of single- } \\
\text { family living with yards; } \\
\text { Penetration of the dense } \\
\text { urban fabric with vast } \\
\text { parks (i.e., urban 'lungs'). }\end{array}$ & $\begin{array}{l}\text { Moderately } \\
\text { dispersed }\end{array}$ & $\begin{array}{l}\text { Low to } \\
\text { moderate }\end{array}$ & $\begin{array}{l}\text { Monumental City idea for } \\
\text { creating parks is maintained; } \\
\text { Garden Cities idea receives a } \\
\text { peculiar mixed interpretation: } \\
\text { Sofia is to disperse and shrink } \\
\text { at the same time; Plan is not } \\
\text { implemented but certain ideas } \\
\text { are carried on in later plans. }\end{array}$ \\
\hline $\begin{array}{l}1945 \\
\text { Tonev }\end{array}$ & $\begin{array}{l}\text { Functional City/ } \\
\text { 'Socialist' reconstruction } \\
\text { and modernization } \\
\text { (some Monumental City) }\end{array}$ & $\begin{array}{l}\text { City needs war } \\
\text { rebuilding but has } \\
\text { limited funds; } \\
\text { Dispersal in garden } \\
\text { towns \& single- } \\
\text { family homes w/ } \\
\text { private yards is a } \\
\text { "bourgeois" idea. }\end{array}$ & YES & Moderate & $\begin{array}{l}\text { Moving certain functions } \\
\text { to periphery; Penetration } \\
\text { of the dense urban fabric } \\
\text { with vast public parks } \\
\text { (i.e., urban 'lungs'); } \\
\text { Providing common green } \\
\text { spaces b/n housing blocks }\end{array}$ & $\begin{array}{l}\text { Relatively } \\
\text { compact }\end{array}$ & Moderate & $\begin{array}{l}\text { Monumental City idea for } \\
\text { creating parks is maintained; } \\
\text { Garden City idea is rejected; } \\
\text { Functional City, esp. in terms } \\
\text { of modernizing infrastructure, } \\
\text { is endorsed and linked to } \\
\text { equalitarian ideology; Plan is } \\
\text { mostly implemented. }\end{array}$ \\
\hline $\begin{array}{l}\text { 1959-1961 } \\
\text { Neikov }\end{array}$ & $\begin{array}{l}\text { Functional City/ } \\
\text { 'Socialist' modernization }\end{array}$ & $\begin{array}{l}\text { City needs to be } \\
\text { modernized; must } \\
\text { be socialist city w/ } \\
\text { equal conditions } \\
\text { _for_all citizens._-_. }\end{array}$ & YES & Moderate & $\begin{array}{l}\text { Moving certain functions } \\
\text { to the urban periphery; } \\
\text { Providing common green } \\
\text { spaces b/n housing blocks }\end{array}$ & $\begin{array}{l}\text { Relatively } \\
\text { compact }\end{array}$ & Moderate & $\begin{array}{l}\text { Similar to Tonev's, plan keeps } \\
\text { close to Functionalist ideals } \\
\text { with communist flavor. Later, } \\
\text { updated in Siromahov's terms. }\end{array}$ \\
\hline Siromahov & $\begin{array}{l}\text { Modernist City/ } \\
\text { 'Socialist' modernization }\end{array}$ & $\begin{array}{l}\text { Must become } \\
\text { polycentric city w/ } \\
\text { modern urban } \\
\text { periphery like the } \\
\text { Soviet examples. }\end{array}$ & YES & Strong & $\begin{array}{l}\text { More substantial moving } \\
\text { of functions from center } \\
\text { to periphery; Massive } \\
\text { common public spaces; } \\
\text { Industrial construction. }\end{array}$ & $\begin{array}{l}\text { Substantial } \\
\text { territorial } \\
\text { expansion }\end{array}$ & $\begin{array}{l}\text { High to } \\
\text { moderate }\end{array}$ & $\begin{array}{l}\text { Full embrace of the ideas of } \\
\text { the Athens Charter with a pro- } \\
\text { Soviet communist } \\
\text { interpretation. Massive spatial } \\
\text { expansion implemented. }\end{array}$ \\
\hline $\begin{array}{l}\text { 1998-2003 } \\
\text { A: Motev/ } \\
\text { Alexandrov }\end{array}$ & $\begin{array}{l}\text { EU spatial planning } \\
\text { City Sustainable } \\
\text { New Regionalism }\end{array}$ & $\begin{array}{l}\text { City has infill } \\
\text { reserves; Dispersal } \\
\text { not fiscally/socially } \\
\text { ecologically sound. }\end{array}$ & YES & Moderate & $\begin{array}{l}\text { Strengthening few nodes } \\
\text { in periphery; Preserving } \\
\text { green spaces outside city; } \\
\text { Limiting suburbia. }\end{array}$ & $\begin{array}{l}\text { Relatively } \\
\text { compact }\end{array}$ & Moderate & $\begin{array}{l}\text { Sustainability/regionalism } \\
\text { strongly endorsed and taken to } \\
\text { mean compact urban forms. }\end{array}$ \\
\hline $\begin{array}{l}\text { B: Stajnov/ } \\
\text { Mihajlovich }\end{array}$ & $\begin{array}{l}\text { EU spatial planning } \\
\text { City Sustainable } \\
\text { New Regionalism }\end{array}$ & $\begin{array}{l}\text { City is dense, has } \\
\text { strong center and } \\
\text { weak suburbs. It is } \\
\text { unlike Western } \\
\text { cities but must } \\
\text { become like them. }\end{array}$ & YES & High & $\begin{array}{l}\text { Substantial strengthening } \\
\text { of the urban periphery; } \\
\text { Providing more green } \\
\text { spaces in private yards; } \\
\text { Promoting suburbia. }\end{array}$ & $\begin{array}{l}\text { Relatively } \\
\text { dispersed }\end{array}$ & $\begin{array}{l}\text { Low to } \\
\text { moderate }\end{array}$ & $\begin{array}{l}\text { Sustainability/regionalism } \\
\text { strongly endorsed and taken to } \\
\text { mean dispersed urban forms. }\end{array}$ \\
\hline
\end{tabular}




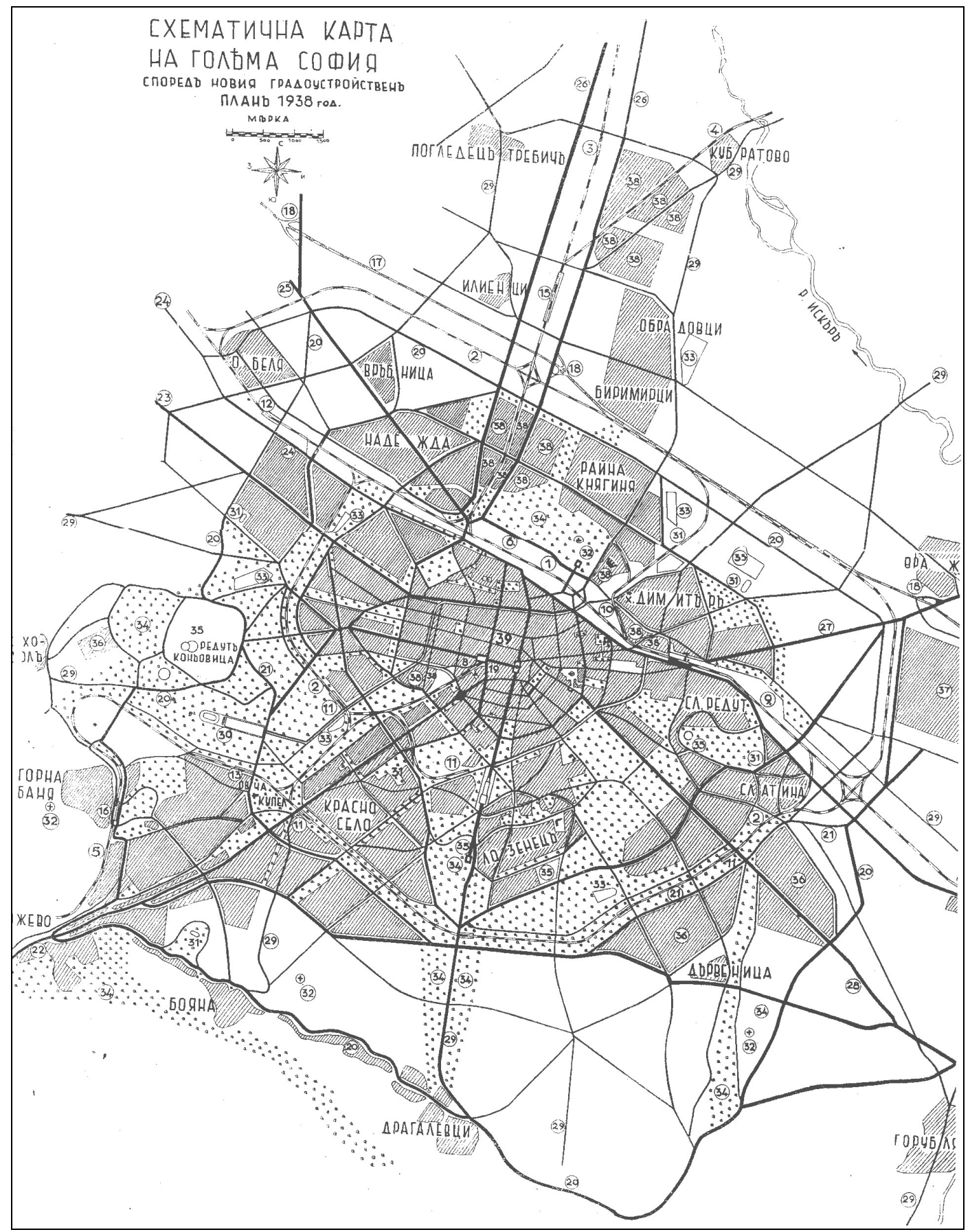

Figure 1: $\quad$ Part of Muesmann's plan, entitled "Planning Scheme of Greater Sofia according to the New Plan from 1938." The dotted areas are the green spaces (or the urban "lungs"), which separate the urbanized zones (i.e., the "Garden Districts"); the latter are shown in dark hatches. The scheme envisione that a few urbanized areas be constructed in the periphery of Sofia but also designated several existing built-out areas for wholesale clearance and conversion to greenbelts. The plan was embedded in Western rhetoric for the virtues of Garden Cities but had difficulties in reconciling its verbose endorsement of urb dispersal with its proposals for the actual "shrinking" of parts of Sofia. 


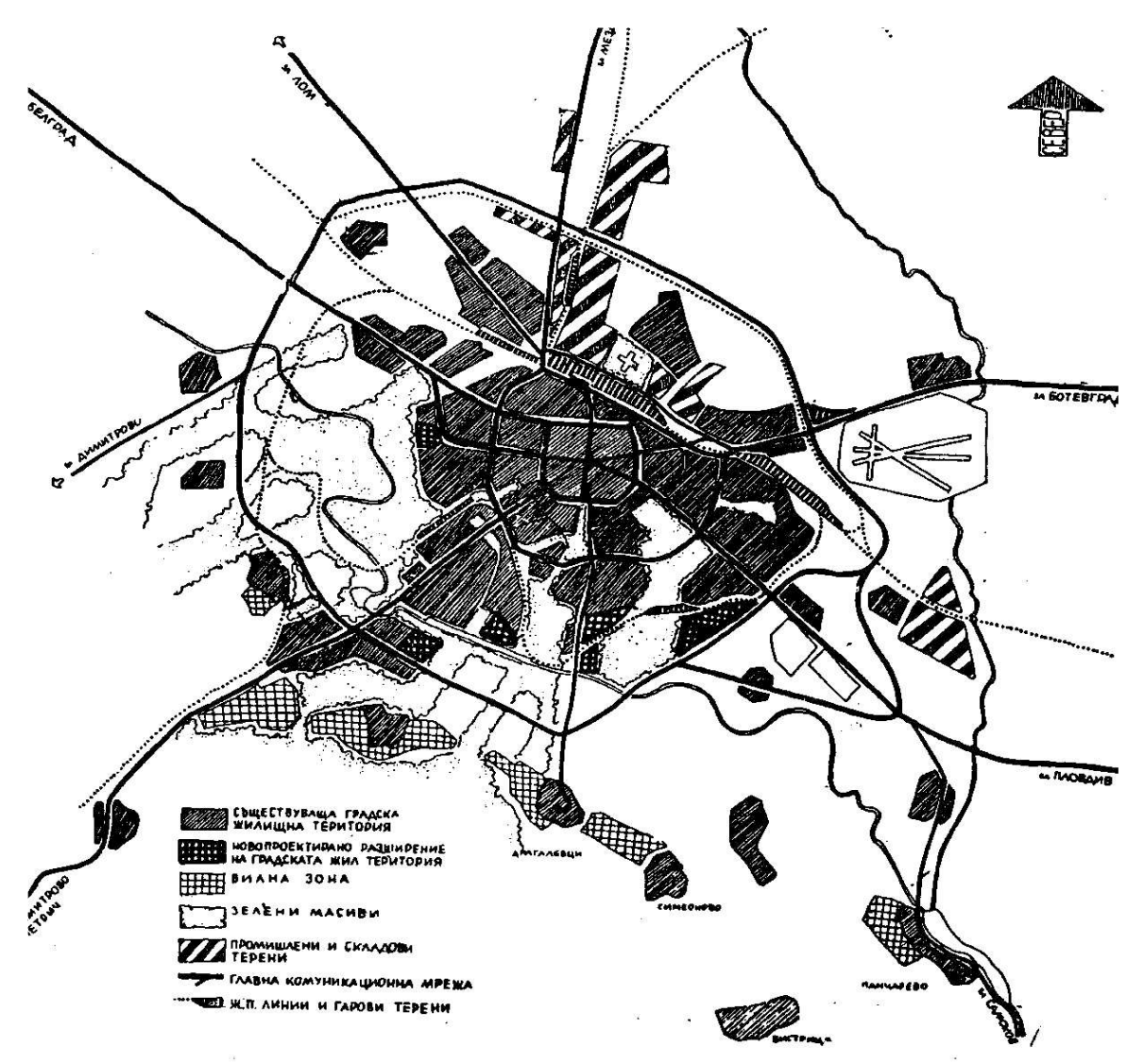

Figure 2: Neikov's scheme of Sofia from 1961. The urban residential zones are the darkest areas, which are shaded diagonally and cross-hatched (see the first two boxes in the legend). In-between are the green spaces (shown as lightly dotted; see the fourth category in the legend), which broadly follow the outline of Muesmann's greenbelts. Neikov rejected Muesmann's rhetoric for urban dispersal, promoted Sofia as a compact city, and showed just a couple locations for potential territorial growth.

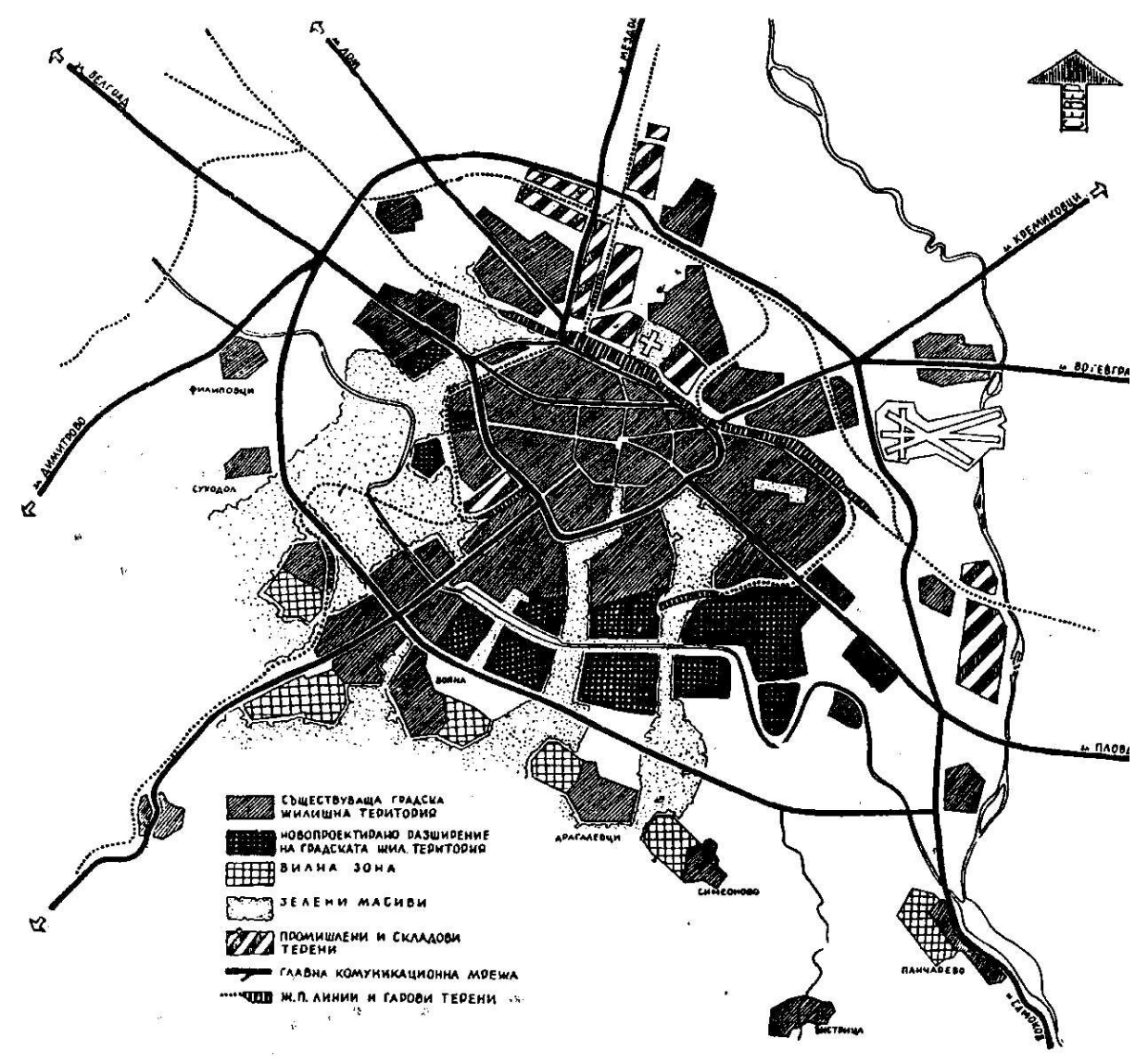

Figure 3: Siromahov's plan from 1961 shows a substantially larger Sofia with several additional new residential zones, especially along the northwest and southeast periphery. Like Neikov, Siromahov stayed away from "bourgeois" notions of quasi-rural dispersal as exacerbating the conflict between center and periphery. But unlike Neikov, Siromahov proposed a strong decentralization scheme under which modern socialist housing estates would develop as equal to the center. Like Neikov, Siromahov showed the residential zones in dark, diagonally and crosshatched tones (see the first two boxes of the legend) and the green snaces as dotted. 


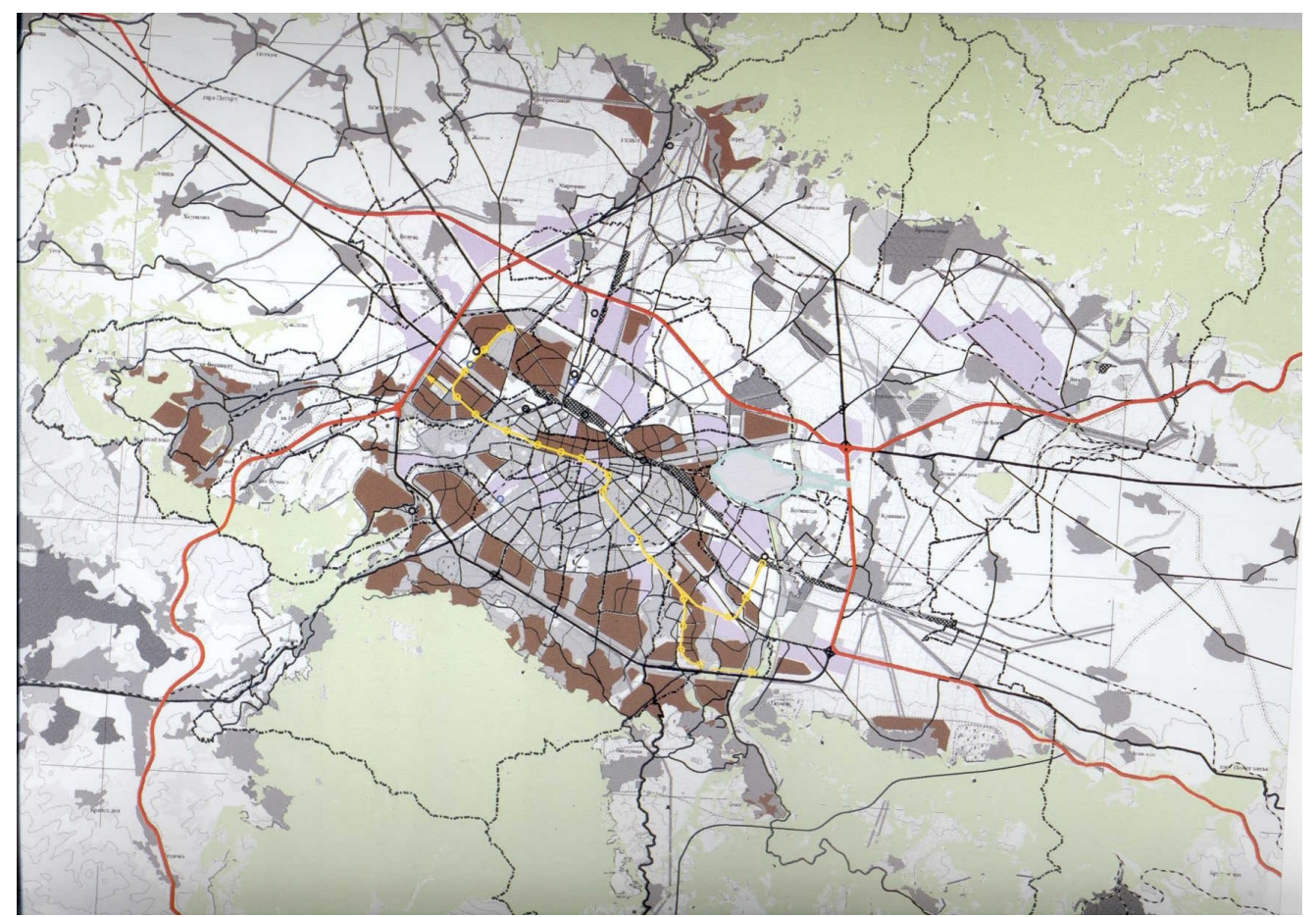

Figure 4: Metropolitan Sofia according to Scenario A. The darkest colored (brown) areas are domina by residential uses (the lighter shaded areas are ostensibly dominated by civic, business or industrial uses

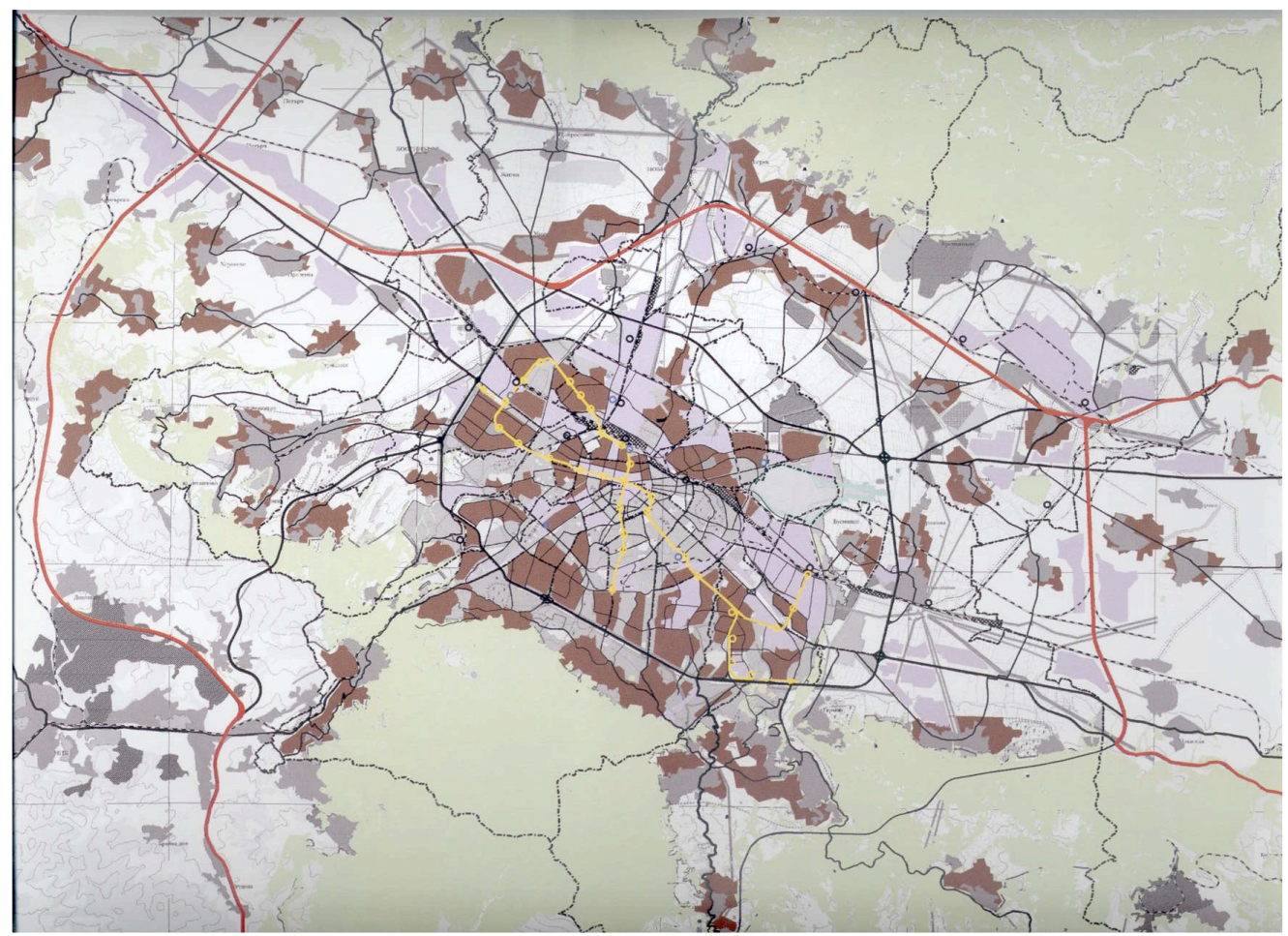

Figure 5: Metropolitan Sofia according to Scenario B. The residential zones (again colored in dark brown) expand farther, especially along the mountain outskirts to the West, North and East of the city. Scenario B was formally endorsed - a testimony to the fact that the urban dispersal idea, dressed in a peculiar interpretation of Western ideas of regionalism and sustainability, has gained new supporters. 
${ }^{1}$ Dobrina Jeleva-Martins, "Bulgarskoto gradoustrojstwo kato krustoput na Iztochnia i Zapadnia Avangard," Arhitektura, no. 2 (2000): 21-24. (In Bulgarian).

Dobrina Jeleva-Martins, "Bulgarskoto gradoustrojstvo po putya na modernizma," Arhitektura,, no. 2 (1994): 36-39. (In Bulgarian).

${ }^{2}$ A. Yerolympos, "Urbanism as social engineering in the Balkans: reform prospects and implementation problems in Thessaloniki" in Urbanism Imported or Exported: Native Aspirations and Foreign Plans, ed. Joe Nasr and Mercedes Volait (Chichester: Wiley, 2003).

Roumen Daskalov, Mezhdu Iztoka i Zapada: Dilemi na Bulgarskata Kulturna Identichnost. (Sofia: Lik, 1998) (In Bulgarian).

${ }^{3}$ Joe Nasr and Mercedes Volait, "Introduction," in Urbanism Imported or Exported: Native Aspirations and Foreign Plans, ed. Joe Nasr and Mercedes Volait (Chichester: Wiley, 2003).

${ }^{4}$ Stephen Ward, Planning the Twentieth-century City: The Advanced Capitalist World (Chichester: Wiley, 2002).

Stephen Ward, "Reexamining the international diffusion in planning," in Urban Planning in a Changing World: Twentieth-century Experience, ed. Robert Freestone (London: Spon, 2000).

5 Joe Nasr and Mercedes Volait, "Introduction," in Urbanism Imported or Exported."

${ }^{6}$ A. Yerolympos, “ Urbanism as Social Engineering" and C. Hein, "The transformation of planning ideas in Japan and its colonies," in Urbanism Imported or Exported.

${ }^{7}$ Peter Hall, Cities of Tomorrow: An Intellectual History of Planning and Design in the Twentieth Century (New York: Blackwell 1988).

${ }^{8}$ Christine M. Boyer, Dreaming the Rational City (Cambridge: MIT Press 1983).

${ }^{9}$ Maria Kaika, City of Flows: Modernity, Nature and the City (New York: Routledge 2005).

${ }^{10}$ G. Marsh, "The study of Nature," in American Environmentalism: The Formative Period, 1860-1915, ed. D. Hall and D. Howe (New York: John Wiley \& Sons, 1973 [1871]).

${ }^{11}$ Christine M. Boyer, "Dreaming the Rational City".

${ }^{12}$ See William Cronon, Nature's Metropolis: Chicago and the Great West, (New York: Norton, 1991).

${ }^{13}$ Fredrick Olmsted, "The urban planners as a civilizing force," in American Environmentalism: The Formative Period, 1860-1915, (New York: John Wiley \& Sons, 1973 [1871]).

${ }^{14}$ Maria Kaika, "City of Flows".

${ }^{15}$ Talen also points out that a focus on reforming the existing city vs. a focus on creating new towns in the city periphery is a key axis that divides the main planning schools of the $20^{\text {th }}$ century into two types. See Emily Talen, New Urbanism and American Planning: The Conflict of Cultures (London: Routledge 2005).

${ }^{16}$ Peter Hall, "Cities of Tomorrow."

Jonathan Barnett, The Elusive City: Five Centuries of Design, Ambition and Miscalculation (New York: Harper \& Row Publishers 1986).

${ }^{17}$ E.g., see E Pinheiro, Europa, Francia and Bahia: Diffusion and adaptation of urban European models. Paper presented at the Conference of the International Planning History Society in Barcelona, 2003.

A. Almandoz, "Longing for Paris: The Europeanized dream of Caracas urbanism, 1870-1940," Planning Perspectives 14, no 3: 225-240 (1999).

${ }^{18}$ Christine M Boyer, Dreaming the Rational City.

${ }^{19}$ Jonathan Barnett, The Elusive City. 
${ }^{20}$ James Holston, The Modernist City: An Anthropological Critique of Brazilia, (Chicago: University of Chicago Press, 1989).

Jonathan Barnett, The Elusive City.

${ }^{21}$ Le Corbusier, The Athens Charter (New York: Grossman Publishers, 1973 [1933]).

${ }^{22}$ Peter Hall, Cities of Tomorrow.

${ }^{23}$ Ebenezer Howard, Garden Cities of Tomorrow: A Peaceful Path to Reform (London: Faber and Faber 1946 [1898]).

${ }^{24}$ Robert Fishman, Bourgeois Utopias: The Rise and Fall of Suburbia (New York: Basic Books, 1987).

Robert Fishman, Urban Utopias in the Twentieth Century: Ebenezer Howard, Frank Lloyd Wright, Le Corbusier (Cambridge: MIT Press, 1982).

${ }^{25}$ David Gordon, Planning Twentieth-century Capital Cities (London: Routledge 2006).

E.g., see also C. Garnaut, and A. Hutchings, "The Colonel Light Gardens Garden Suburb Commission: Building a planned community," Planning Perspectives, 18 (July 2003): 277-293.

B. Izaskun, and D. Landa, "Urban models and transferences in Caracas," Paper presented at the Conference of the International Planning History Society in Barcelona, 2003.

D. Mittner," The influence of the Garden City's idea in Israel and Egypt," Paper presented at the Conference of the International Planning History Society in Barcelona, 2003.

${ }^{26}$ Lewis Mumford, The Culture of Cities (New York: Harcourt Brace Jovanovich, 1938).

${ }^{27}$ Patrick Geddes, Cities in Evolution (London: Williams \& Norgate 1949 [1915]).

Stephen Wheeler, "Planning for metropolitan sustainability," Journal of Planning Education and Research 20, no 2 (2000): 133-145.

Robert Fishman, "The death and life of American regional planning," in Reflections on Regionalism, ed. Brice Katz (Washington DC: Brookings Institution Press, 2000).

${ }^{28}$ Mary Sies and Christopher Silver, "Conclusion: Planning history and the new American metropolis," in Planning the Twenty-Century American City, ed. Mary Sies and Christopher Silver (Baltimore: John Hopkins University Press, 1996).

${ }^{29}$ Richard Stites, "Utopia in space: City and building," in Revolutionary Dreams: Utopia Dreams and Experimental Life in the Russian Revolution (Oxford: Oxford University Press, 1989).

${ }^{30}$ Frank Lloyd Wright, The Disappearing City (New York: Payson, 1932).

${ }^{31}$ E.g., P. Self, “The evolution of the Greater London Plan, 1944-1970," Progress in Planning 57, no 3-4 (2002): 145-175.

Stephen Wheeler, "Planning for Metropolitan Sustainability."

${ }^{32}$ Robert Fishman, Bourgeois Utopias.

${ }^{33}$ Jane Jacobs, The Death and Life of Great American Cities, 19-20 (New York: Random 1961).

${ }^{34}$ Stephen Wheeler, "The new regionalism: Key characteristics of an emerging movement," Journal of the American Planning Association 68, no 3 (2002): 267-278.

Robert Fishman, "The death and life of American regional planning."

Mary Sies and Christopher Silver, "Conclusion."

${ }^{35}$ Peter Hall, Cities of Tomorrow.

${ }^{36}$ E.g., Holmes Rolston, Environmental Ethics: Duties to and Values in the Natural World (Philadelphia: Temple University Press, 1988) 
T. Regan, "The nature and possibility of an environmental ethic," Environmental Ethics 3 (1982): 19-34

${ }^{37}$ Ian McHarg, Design with Nature (New York: American Museum of Natural History, 1971).

${ }^{38}$ Martha Conroy, "Moving the middle ahead: Challenges and opportunities of sustainability in Indiana, Kentucky and Ohio," Journal of Planning Education and Research 26, no 1 (2006): 18-27.

M Whitehead, "(Re)analyzing the sustainable city: Nature, urbanization and socio-environmental relations in the UK," Planning Perspectives 40, no 7 (2003): 1183-1206.

${ }^{39}$ According to the UN's Brundtland Report from 1987 sustainable development is development that "meets the needs of the present without compromising the ability of future generations to meet their own needs."

${ }^{40}$ Scott Campbell, "Green cities, growing cities, just cities? Urban planning and the contradictions of sustainable development," Journal of the American Planning Association 62, no 3 (1996): 296-312.

${ }^{41}$ U. Wikan, "Sustainable development in the Mega-City," Current Anthropology 36, no 4 (1995): 635655.

${ }^{42}$ Sonia Hirt, “Toward post-modern urbanism: Evolution of planning in Cleveland, Ohio," Journal of Planning Education and Research 25, no 1 (2005): 27-42.

Emily Talen and Gerrit Knaap, "Legalizing smart growth: An empirical study of land use regulation in Illinois" Journal of Planning Education and Research 22, no 4 (2003): 345-359.

Stephen Wheeler, "The new regionalism."

Stephen Wheeler, "Planning for metropolitan sustainability."

Congress for New Urbanism, New Urbanism: Comprehensive Report \& Best Practices Guide. (Ithaca: New Urban Publications, 2001).

P. Healey, and R Williams, "European urban planning systems: Diversity and convergence," Urban Studies 30, no 4/5 (1993): 701-720.

${ }^{43}$ Stephen Wheeler, "The new regionalism."

${ }^{44}$ European Environment Agency, Environment in the European Union at the Turn of the Century. (Brussels: European Environment Agency, 1998).

American Planning Association, PAS Report 479: Principles of Smart Development (Chicago: American Planning Association, 1998).

President's Council on Sustainable Development, Sustainable America: A New Consensus for Prosperity, Opportunity, and a Healthy Environment for the Future (Washington, DC: Government Printing Office, 1996).

United Nations, Agenda 21 (New York: United Nations, 1992).

${ }^{45}$ Dobrina Jeleva-Martins, "Bulgarskoto gradoustrojstvo," Arhitektura, no 2 (1994): 36-39. (In Bulgarian)

${ }^{46}$ Camden Staddon and Bellin Mollov, "City profile: Sofia, Bulgaria," Cities 17, no 5 (2000): 379-387.

${ }^{47}$ See Dobrina Jeleva-Martins, "Horizontalna organizacia na grada: Sinhronen analiz," Arhitektura, no 3/4 (1991): 25-28. (In Bulgarian).

${ }^{48}$ Peter Tashev, "Urbanization in Bulgaria," in International History of City Development, Vol. VIII: Urban Development in Eastern Europe, Bulgaria, Romania and the U.S.S.R, E. Gutkind (New York: Free Press, 1972a).

Peter Tashev, Sofia: Arhitekturno i Gradoustrojstveno Razvitie: Etapi, Postijenija i Problemi (Sofia: Tehnika, 1972b) (In Bulgarian).

${ }^{49}$ Dobrina Jeleva-Martins, "Izbrani fakti i komentar za purviya regulacionen plan na stolicata," Arhitektura, no 2 (1999): 38- 40 and no 3 (1999): 38-40. (In Bulgarian) 
${ }^{50}$ A. Ishirkov, "Naselenieto na Sofia," in Jubilejna Kniga na Grad Sofia (Sofia: Knipegraph, 1928). (In Bulgarian)

${ }^{51}$ Gyorgi Labov, Arhitekturata na Sofia (Sofia: Tehnika, 1979). (In Bulgarian).

${ }^{52}$ John Lampe, "Interwar Sofia versus the Nazi-style Garden City: The struggle over the Muesmann Plan." Journal of Urban History 11, no 1 (1984): 39-62.

${ }^{53}$ D. Jurdanov, "Sofia kato industrialen center," in Jubilejna Kniga na Grad Sofia. (Sofia: Knipegraph, 1928). (In Bulgarian).

${ }^{54}$ John Lampe, "Interwar Sofia."

${ }^{55}$ Stolichna Goliama Obshtina, Izgrajdaneto na Golyama Sofia: Kakvo Predvijda Musmanovia Plan, 6. (Sofia: Stolichna Goliama Obshtina, 1938) (In Bulgarian).

${ }^{56}$ See John Lampe, "Interwar Sofia."

${ }^{57}$ Sonia Hirt, "Planning the post-communist city: Experiences from Sofia," International Planning Studies, 10, no 3/4 (2005): 219-239

And Dobrina Jeleva-Martins, "Horizontalna organizacia na grada."

${ }^{58}$ Dobrina Jeleva-Martins, "Bulgarskoto gradoustrojstvo po putya na modernizma."

${ }^{59}$ Todor Goranov, "Pulni avtentichni obyasnenya po Musmanovia plan," Zora, 5669: 30, May 19, 1938. (In Bulgarian)

${ }^{60}$ John Lampe, "Interwar Sofia."

${ }^{61}$ Dobrina Jeleva-Martins, "Doktrinata na modernizma: Interpretacia na Musmanovija plan na Sofia," Arhitektura, no 5 (1998): 36-39. (In Bulgarian)

${ }^{62}$ Ivan Ivanov, "Rech na stolichnia kmet Ingener Ivan Ivanov po gradoustrojstvenia plan na Sofia, izraboten ot professor Musman, proiznesena pred Stolichniya Obshtinski Suvet na 18 maj 1938 g," in Izgrajdane na Budeshta Golyama Sofia: Kakvo Predvijda Musmanovia Plan. (Sofia: Stolichna Golyama Obshtina, 1938). (In Bulgarian).

Stolichna Golyama Obshtina, "Izgrajdaneto na Golyama Sofia,"41.

Adolph Muesmann, "Gradoustrojstevenite problemi na Sofia" Spisanie na Bulgarskoto InjenernoArhitekturno Drujestvo, no 17/18 (1936): 169-172. (In Bulgarian)

${ }^{63}$ Todor Goranov, "Pulni avtentichni obyasnenya," 30.

${ }^{64}$ Sonia Hirt, "Centralization or decentralization: Sustainable Development (or not) in planning the City of Sofia, Bulgaria," in Sustainable Planning \& Development, 847-857. (Southampton: WIT Press, 2003).

${ }^{65}$ Stolichna Goliama Obshtina, "Izgrajdaneto na Golyama Sofia,” 29.

John Lampe, "Interwar Sofia"

${ }^{66}$ John Lampe, "Interwar Sofia."

${ }^{67}$ Stolichna Goliama Obshtina, "Izgrajdaneto na Golyama Sofia," 49-70.

${ }^{68}$ E.g., K Karat, The Gecekondu: Rural Migration and Urbanization (Cambridge: Cambridge University Press, 1976).

${ }^{69}$ J Pino, “On the history of favelas in Rio de Janeiro," Latin American Research Review 32, no 3 (1997): 111-122.

${ }^{70}$ John Lampe, "Interwar Sofia."

${ }^{71}$ Stolichna Goliama Obshtina, "Izgrajdaneto na Golyama Sofia," 13-15, 43 
${ }^{72}$ Protokoli ot Sreshtite na Ingener Ivanov s Grajdanska Delegacia Dokladvashta Opozicia kum Musmanovia Plan, 6 (Sofia: Sofia Archives, Source 1K, Part 3, Archival Unit 482, July 27, 1938) (In Bulgarian).

${ }^{73}$ Sonia Hirt, "Planning the post-communist city."

John Lampe, "Interwar Sofia."

${ }^{74}$ Naredba-zakon za izmenenie na Obshtija Gradoustrojstven plan na Sofia i Stolichnata Goliama Obshtina, Durjaven Vestnik, no 29, 1945. (In Bulgarian)

75 Jordan Tangurov, “Modernata arhitektura 1944-1990,” Arhitektura, no 2 (2000): 46-48. (In Bulgarian)

Lyuben Tonev, "Golemite greshki na plana Musman," in Po Putya na Bulgarskoto Gradoustrojstvo (Sofia: Izdatelstvo na Bulgarskata Akademia na Naukite, 1987 [1939]). (In Bulgarian)

${ }^{76}$ Peter Tashev, Sofia: Arhitekturno i Gradoustrojstveno Razvitie: Etapi, Postijenija i Problemi, 30 (Sofia: Tehnika, 1972). (In Bulgarian).

${ }^{77}$ Dobrina Jeleva-Martins, "Doktrinata na modernizma."

${ }^{78}$ Lyuben Tonev, "Za Generalnia Plan na Sofia ot 1945 godina,” Arhitektura, no 7/8 (1992): 26-36. (In Bulgarian).

Lyuben Tonev, "Golemite greshki na plana Musman," 436-438.

${ }^{79}$ Lyuben Neikov and Boris Samodumov, Uchebnik po gradoustrojstvo, 177-81 (Sofia: Narodna Prosveta 1952). (In Bulgarian).

${ }^{80}$ See Atanas Kovachev, Zelenata Sistema na Sofia.

D. Mushev, "Za stolicata i nejnite proektanti," Arhitektura, no 7/8 (1992): 21-23. (In Bulgarian).

Gyorgi Labov, Arhitekturata na Sofia.

${ }^{81}$ Zakon za priemane i prilagane na Obshtija Gradoustrojstven Plan na Sofia, Durjaven Vestnik, no 89, 1961. (In Bulgarian)

${ }^{82}$ Lyuben Tonev, "Problemi na noviya gradoustrojstven plan na Sofia," in Po Putya na Bulgarskoto Gradoustrojstvo (Sofia: Izdatelstvo na Bulgarskata Akademia na Naukite, 1987 [1959], 442-445.

${ }^{83}$ David Crowley and Susan Reid, Socialist Spaces: Sites of Everyday Life in the Eastern Bloc, eds. (Oxford: Berg, 2002).

${ }^{84}$ Peter Lizon, "East Central Europe: The unhappy heritage of communist mass housing," Journal of Architectural Education 50, no 2 (1996): 104-114.

${ }^{85}$ D. Mushev, "Za stolicata i neynite proektanti."

${ }^{86}$ Gyorgi Andrusz, "Structural change and boundary instability," in Cities after Socialism: Urban and Regional Change and Conflict in Post-Socialist Societies, eds. Gyorgy Andrusz, Michael Harloe and Ivan Szelenyi (Oxford: Blackwell, 1996).

${ }^{87}$ Robert Buckley and Sasha Tsenkova, Strategia za Razvitie na Grad Sofia: Predvaritelna Ocenka. (Sofia: Stolichna Obshtina, 2001). (In Bulgarian).

${ }^{88}$ A. Yoveva, D. Dimitrov and R. Dimitrova, "Housing policy: The stepchild of the transition," in Housing Policy: An End or a New Beginning, ed., M. Lux (Budapest: Open Society Institute, Local Government and Public Reform Initiative, 2003).

${ }^{89}$ A. Elbers, and S. Tsenkova, "Housing a nation of home owners-reforms in Bulgaria," in Housing Change in East Central Europe, ed. S. Lowe and S. Tsenkova (Aldershot: Ashgate, 2003).

${ }^{90}$ Nacionalen Statisticheski Institut. Sofia v Cifri. (Sofia: Nacionalen Statisticheski Institut, Stolichno Teritorialno Bjuro, 2001). (In Bulgarian) 
Nacionalen Statisticheski Institut. Statisticheski Sbornik—Sofia. (Sofia: Nacionalen Statisticheski Institut, Stolichno Teritorialno Bjuro, 1993). (In Bulgarian)

${ }^{91}$ Sonia Hirt and Atanas Kovachev, "The changing spatial structure of post-socialist Sofia," in The Urban Mosaic of Post-socialist Europe: Space, Institutions and Policy, eds. Sasha Tsenkova and Zorica NedovicBudic (Heidelberg: Springer/Physica-Verlag 2006).

Camden Staddon and Bellin Mollov, "City profile: Sofia, Bulgaria."

G. Genov, P. Slavejkov, and H. Ganev, "Urbanizirani teritorii," in Sofia: 120 Godini Stolica. (Sofia: Academichno Izdatelstvo Profesor Marin Drinov, 2000) (In Bulgarian).

${ }^{92}$ Dobrina Jeleva-Martins, "Sofia i selishtata: Budeshte za minaloto," Aspekti, no 6 (1995): 14-20. (In Bulgarian).

Alexander Alexandrov, "Noviyat Generalen Plan na Sofia mejdu vchera i dnes," Arhitektura, no 7/8: (1992): 30-48 (In Bulgarian).

93 "Zakon za izmenenie na zakona za podgotovka, priemane i prilagane na Obshtija Ustrojstven Plan na Sofia," Durjaven Vestnik, no 41, 1998, (In Bulgarian).

${ }^{94}$ Sonia Hirt, "Planning the post-communist city."

${ }^{95}$ N. Karadimov, "Konkurs za budeshteto na grada: dumata na jurito," Grad v Polite na Vitosha, no 2 (2001): 2-6.

${ }^{96}$ Peter Dikov, "Scenarii za socialno-ikonomichesko i prostranstveno razvitie na Sofia i Stolichnata Obshtina v perioda do 2020 g," Arhitektura, no 4 (2001): 29-31. (In Bulgarian).

Vesselina Troeva, "Vajen etap ot podgotovkata na Obshtija Ustrojstven Plan na Sofia," Arhitektura, no 4 (2001): 32-33. (In Bulgarian)

${ }^{97}$ Stolichna Obstina, Obsht Ustrojstven Plan na Grad Sofia i Stolichnata Obshtina: Faza Predvaritelen Proekt, Etap 2, Scenarii za Socialno-ikonomichesko i Teritorialno Razvitie na Grad Sofia za Perioda do 2020 g, (Sofia: Stolichna Obshtina, 2001). (In Bulgarian).

${ }^{98}$ Stolichna Obstina, Obsht Ustrojstven Plan na Grad Sofia.

${ }^{99}$ Stolichna Obshtina, Obsht Ustrojstven Plan na Grad Sofia i Stolichnata Obshtina: Faza Predvaritelen Proekt, Etap 3, Idejni Proekti za Teritorialno Razvitie na Grad Sofia i Stolichna Obshtina (Sofia: Stolichna Obshtina, 2002). (In Bulgarian)

${ }^{100}$ According to official data, Sofia has density of 57.5 persons per ha. This compares to 42.3 persons per ha in London, 46.6 in Paris and 48.8 in Amsterdam (J. Kenworthy and F. Laube, An International Sourcebook of Automobile Dependence in Cities, 1960-1990, et al. (Boulder: University of Colorado Press, 1999).

${ }^{101}$ As of 2000, the highest residential density in Sofia, 180 people per ha, was within a radius of $1 \mathrm{~km}$ of the heart of downtown (see Robert Buckley and Sasha Tsenkova, Strategia za Razvitie na Grad Sofia, 72). Densities tend to decrease toward the periphery with the partial exception of the socialist housing estates.

${ }^{102}$ According to data made available to the author by Colliers International, as of 2003, Sofia's center held around half of the total office space in the metropolis.

${ }^{103}$ According to data from real estate agencies in Sofia, in July 2005 housing prices in Vitosha averaged 654 Euros per sq m, while in the center (e.g., Oborishte district) they were 769 Euros per sq m.

${ }^{104}$ Zorica Nedovic-Budic, "Adjustment of planning practice to the new Eastern and Central European context," Journal of the American Planning Association 67, no 1 (2001): 38-52. 